\title{
EXOGENOUS SALICYLIC ACID AND CYTOKININ ALTER SUGAR ACCUMULATION, ANTIOXIDANTS AND MEMBRANE STABILITY OF FABA BEAN
}

\author{
Samira Samea-AndabJadid, ${ }^{1}$ KaZem GhasSemi-GoleZani, ${ }^{1}$ * \\ Safar NasrollahZadeH ${ }^{1}$ and Nosratollah NAJAFI ${ }^{2}$ \\ ${ }^{1}$ Department of Plant Eco-physiology, Faculty of Agriculture, University of Tabriz, Tabriz, Iran \\ ${ }^{2}$ Department of Soil Science, Faculty of Agriculture, University of Tabriz, Tabriz, Iran
}

(Received: August 24, 2017; accepted: October 30, 2017)

\begin{abstract}
This research was conducted in a greenhouse to evaluate the effects of exogenous application of salicylic acid (SA) $(1 \mathrm{mM})$ and 6-benzylaminopurine (BAP) $(50 \mu \mathrm{M})$ on physiological performance of faba bean (Vicia faba) under different levels of $\mathrm{NaCl}$ salinity $(0,4,8$ and $12 \mathrm{dS} / \mathrm{m}$ ). The experiment was arranged as factorial on the bases of randomized complete block design in three replications. Leaf $\mathrm{Na}^{+}$content, root and leaf soluble sugars, antioxidant enzymes activities such as catalase (CAT), ascorbate peroxidase (APX), superoxide dismutase (SOD) and lipid peroxidation increased, but $\mathrm{K}^{+}, \mathrm{K}^{+} / \mathrm{Na}^{+}$and membrane stability index (MSI) decreased as a result of salt stress. However, foliar sprays of BAP and particularly $\mathrm{SA}$ reduced $\mathrm{Na}^{+}$content and lipid peroxidation, while enhanced the $\mathrm{K}^{+}$content, $\mathrm{K}^{+} / \mathrm{Na}^{+}$, soluble sugars, antioxidant enzymes activities and MSI under different levels of salinity. It was, therefore, concluded that exogenous application of these growth regulators (GR) can considerably improve salt tolerance and physiological performance of faba bean.
\end{abstract}

Keywords: Antioxidant enzymes - 6-benzylaminopurine - faba bean - salinity - salicylic acid

\section{INTRODUCTION}

Faba bean (Vicia faba L.) or broad bean is an important tropical and subtropical grain legume with high levels of protein, vitamins (A, B, C) and minerals (e.g iron). It is beneficial to soil fertility because of nitrogen fixation, especially in sandy soils [1]. The production of broad bean could be limited by environmental stresses such as salinity. It is considered moderately sensitive to salt [23] and growth reduction of about 50 percent at $6.7 \mathrm{dS} / \mathrm{m}$ salinity was recorded [26].

Salinity can cause an irreversible loss in yield potential of many crops [18, 29]. High salinity has adverse effects on different aspects of crop growth such as cell enlargement and division [27] and photosynthesis [30]. Subjection of plants to salt stress enhances reactive oxygen species (ROS) [45]. Under normal condition, ROS is also produced continuously in plant cells, due to their role in cell signaling, but when generated severely leads to oxidative stress. ROS are responsible for breaking DNA,

\footnotetext{
*Corresponding author; e-mail address: golezani@gmail.com
} 
lipid peroxidation and oxidation of amino acids [21], leading to the loss of cell viability. Reactive oxygen species (ROS) can be removed by antioxidant enzymes such as superoxide dismutase (SOD), catalase (CAT), ascorbate peroxidase (APX), guaiacol peroxidase (GPX), and non-enzymatic low molecular metabolites such as sugar and proline [34]. Under optimal conditions, coordination between ROS generation and their removal is regulated by antioxidant defense system [17]. The major effect of salinity on plant growth has been related with toxic effect of ions and nutrient imbalance and limitation of water availability [33]. Some of the harmful effects of salt stress on plants could be overcome by exogenous application of plant growth regulators (PGR) such as salicylic acid and cytokinins.

Salicylic acid (SA) is involved in signal transduction in response to abiotic and biotic stresses as a messenger [10]. Foliar spray of this hormone mitigated the damaging effects of salinity, so enhancing salt tolerance of plants. SA plays a major role in stomatal conductance, transpiration and finally photosynthetic rate [3], inhibiting $\mathrm{Cl}^{-}$and $\mathrm{Na}^{+}$accumulation [15] and improving antioxidant defense [42].

Cytokinins (CKs) are considered as the most important senescence-retarding hormones and their exogenous application has been shown to promote conversion of etioplasts into chloroplasts, leaf expansion, and delay leaf senescence [32]. Cytokinins can also enhance resistance to salinity [5]. Kinetin as a synthetic cytokinin is a free radical scavenger, which involved in antioxidant defense [9]. Thus, this research was undertaken to investigate the possible roles of these hormones on improving salt tolerance of faba bean.

\section{MATERIALS AND METHODS}

\section{Experimental design and sowing}

The experiment was conducted as factorial on the basis of randomized complete block design (RCBD) with three replicates in 2016 (Tabriz, Iran). Twenty seeds of faba bean were sown at a depth of $3 \mathrm{~cm}$ in each pot $(25 \times 25 \mathrm{~cm})$ containing $1.0 \mathrm{~kg}$ perlite. Subsequently, tap water and saline solutions $(4,8$, and $12 \mathrm{dS} / \mathrm{m})$ were added to achieve $100 \%$ field capacity (FC). All pots were placed inside a glass greenhouse under natural light. After seedling establishment, plants in each pot were reduced to 10 plants per pot by thinning. The pots were weighed regularly during the experiment and the losses were compensated by Hoagland solution (electrical conductivity $=1.3 \mathrm{dS} / \mathrm{m}, \mathrm{pH} 6.5-7.0$ ). The pots were washed every 30 days and then retreated accordingly, in order to prevent further rise in electrical conductivity due to using the Hoagland solution. Salicylic acid $(1 \mathrm{mM})$ and a synthetic cytokinin (6-benzylaminopurine, $50 \mu \mathrm{M}$ ) were sprayed on plants at vegetative and pod formation stages. 


\section{Measurement of $\mathrm{K}^{+}$and $\mathrm{Na}^{+}$in leaves}

Leaves of a random plant from each pot were detached at pod filling stage and dried at $60{ }^{\circ} \mathrm{C}$ for $48 \mathrm{~h}$. Then $1 \mathrm{~g}$ of dry leaves was powdered and burned at $560{ }^{\circ} \mathrm{C}$ and the ashes digested in $10 \mathrm{~mL}$ of $1 \mathrm{~N} \mathrm{HCl}$. The $\mathrm{Na}^{+}$and $\mathrm{K}^{+}$contents in the digested samples were determined, using a flame photometer (Corning flame photometer, 410).

\section{Measurement of soluble sugars}

Soluble sugars were extracted from plant tissues by phenol sulfuric acid method [24]. Ten $\mathrm{mL}$ of $70 \%$ ethanol was added to $0.1 \mathrm{~g}$ fresh leaf tissue and samples were kept in refrigerator for a week. After adding $2 \mathrm{~mL}$ of distilled water, $1 \mathrm{~mL}$ of $5 \%$ phenol and $5 \mathrm{~mL}$ of sulfuric acid, absorbance was read by a spectrophotometer (Dynamica, Halo DB-20-UV-Visible Spectrophotometer, United Kingdom) at $485 \mathrm{~nm}$. Amount of soluble sugars was calculated by glucose standard curve.

\section{Antioxidant enzymes activities}

In order to assay the antioxidant enzymes activities, soluble proteins were extracted according to Bradford [6]. Catalase (CAT) activity was estimated according to Aebi [2]. The reaction mixture contained $30 \mathrm{mM} \mathrm{H}_{2} \mathrm{O}_{2}, 50 \mathrm{mM}$ phosphate buffer ( $\mathrm{pH} 7.0$ ) and $0.1 \mathrm{~mL}$ enzyme extract. CAT activity was determined by decreased absorbance of $\mathrm{H}_{2} \mathrm{O}_{2}$ at $240 \mathrm{~nm}$.

The reaction solution containing $50 \mathrm{mM}$ potassium phosphate $(\mathrm{pH} 7.0), 0.2 \mathrm{mM}$ EDTA, $0.5 \mathrm{mM}$ ascorbic acid, $2 \% \mathrm{H}_{2} \mathrm{O}_{2}$, and $0.1 \mathrm{~mL}$ of enzyme extract was used to determine the ascorbate peroxidase (APX) activity. APX activity was determined by recording the decrease in absorbance at $290 \mathrm{~nm}$ for 1 min caused by ascorbic acid oxidation. The activity of APX was calculated using the extinction coefficient $\varepsilon=\left(2.8 \mathrm{mmol} \mathrm{L}^{-1} \mathrm{~cm}^{-1}\right)$. One unit APX activity was defined as $1 \mathrm{mmol}$ ascorbate oxidized/mL per min [31].

In order to assay the activity of superoxide dismutase (SOD), reaction mixture contained $50 \mathrm{mM}$ phosphate buffer, $13 \mathrm{mM}$ methionine, $75 \mu \mathrm{M}$ tetrazolium, $2 \mu \mathrm{M}$ riboflavin, $0.1 \mathrm{mM}$ EDTA, $0.1 \mathrm{~mL}$ enzyme extract. One unit of SOD was the amount of enzyme required for $50 \%$ inhibition of nitro blue tetrazolium (NBT) reduction in $560 \mathrm{~nm}[14]$.

\section{Determination of lipid peroxidation}

Lipid peroxidation level was measured by malondialdehyde (MDA) content in reaction mixture. Fresh leaf samples were placed in $5 \mathrm{~mL}$ of $0.1 \%(\mathrm{w} / \mathrm{v})$ trichloroacetic acid (TCA). Following centrifugation at 1000 for $20 \mathrm{~min}, 1 \mathrm{~mL}$ of the supernatant 
was added to $4 \mathrm{~mL}$ of $0.5 \%(\mathrm{w} / \mathrm{v})$ thiobarbituric acid (TBA) in $20 \%(\mathrm{w} / \mathrm{v}) \mathrm{TCA}$. Samples were heated at $90{ }^{\circ} \mathrm{C}$ for $30 \mathrm{~min}$ and were cooled in ice bath. Absorbance of the supernatant was recorded at $532 \mathrm{~nm}$ with a spectrophotometer and was corrected for nonspecific turbidity by subtraction of the absorbance at $600 \mathrm{~nm}$ [8].

\section{Membrane stability index}

Leaf sample ( $0.3 \mathrm{~g}$ fresh leaf from each pot) was placed in a test tube with $15 \mathrm{~mL}$ distilled water. The samples were subjected to $25^{\circ} \mathrm{C}$ for $2 \mathrm{~h}$, and then the initial electrical conductivity $\left(\mathrm{EC}_{1}\right)$ of each sample was measured. Subsequently, the samples were placed at $100{ }^{\circ} \mathrm{C}$ for $30 \mathrm{~min}$ and after cooling down to $25^{\circ} \mathrm{C}$, the conductivity $\left(\mathrm{EC}_{2}\right)$ was measured again. Membrane stability index was calculated using: Membrane stability index $=\left(\mathrm{EC}_{1} / \mathrm{EC}_{2}\right) \times 100$.

\section{Statistical analysis}

Statistical analysis of the data was performed with MSTAT-C software. Duncan multiple range test was applied to compare means of each trait at $\mathrm{P} \leq 0.05$.

\section{RESULTS}

\section{Leaf $\mathrm{Na}^{+}$and $\mathrm{K}^{+}$contents and $\mathrm{K}^{+} / \mathrm{Na}^{+}$ratio}

The leaf $\mathrm{Na}^{+}$and $\mathrm{K}^{+}$contents and $\mathrm{K}^{+} / \mathrm{Na}^{+}$ratio were significantly $(\mathrm{P} \leq 0.01)$ affected by salinity and growth regulators treatments. The $\mathrm{Na}^{+}$content was linearly enhanced with enhancing salinity. However, the $\mathrm{K}^{+}$content was decreased as a result of salinity. Foliar sprays of SA and BAP reduced the $\mathrm{Na}^{+}$content and improved the $\mathrm{K}^{+}$con-
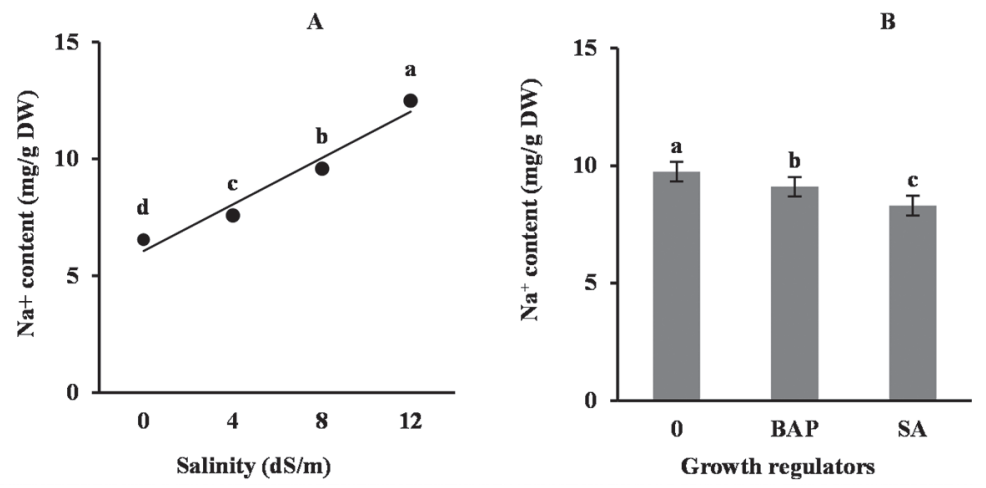

Fig. 1. Changes in $\mathrm{Na}^{+}$content of faba bean leaves under different salinity (A) and growth regulators (B) treatments. Different letters indicate significant difference at $\mathrm{P} \leq 0.05$ 

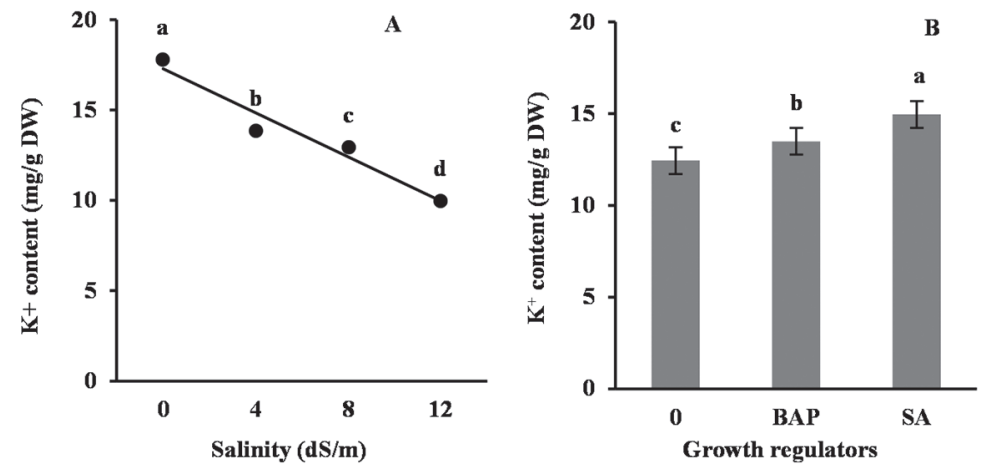

Fig. 2. Changes in $\mathrm{K}^{+}$content of faba bean leaves under different salinity (A) and growth regulators (B) treatments. Different letters indicate significant difference at $\mathrm{P} \leq 0.05$
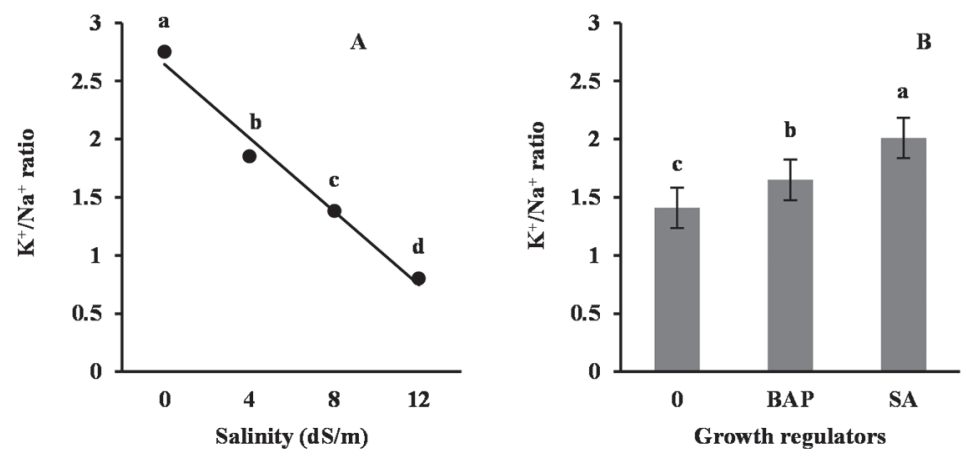

Fig. 3. Changes in $\mathrm{K}^{+} / \mathrm{Na}^{+}$ratio of faba bean leaves under different salinity (A) and growth regulators (B) treatments. Different letters indicate significant difference at $\mathrm{P} \leq 0.05$

tent, leading to an increased ratio of $\mathrm{K}^{+} / \mathrm{Na}^{+}$. The highest $\mathrm{K}^{+}$and the lowest $\mathrm{Na}^{+}$and eventually the maximum $\mathrm{K}^{+} / \mathrm{Na}^{+}$ratio were attained in plants treated with SA (Figs $1,2,3)$.

\section{Root and leaf soluble sugars}

The interaction of salinity $\times$ growth regulators was significant for $\operatorname{root}(\mathrm{P} \leq 0.05)$ and leaf $(\mathrm{P} \leq 0.01)$ soluble sugars. Soluble sugar contents of root and leaf were generally increased under salinity treatment, particularly under $8 \mathrm{dS} / \mathrm{m} \mathrm{NaCl}$. The highest soluble sugars both in root and leaf under different saline conditions were recorded for SA treated plants, followed by BAP treatment. This superiority was also more pronounced under moderate salinity (Table 1 ). 


\section{Antioxidant enzymes activities}

The interaction of salinity $\times$ growth regulators (GR) for antioxidant enzymes activities was also significant $(\mathrm{P} \leq 0.01)$. The activities of antioxidant enzymes including CAT, APX and SOD in GR treated and non-treated plants increased with increasing salinity up to $8 \mathrm{dS} / \mathrm{m}$ and thereafter slightly decreased. These enzymes were most activated by foliar spray of SA under all levels of salinity. Treatment with BAP also improved enzymes activities, compared with untreated plants. The advantage of GR treatments on antioxidant enzymes activities was more evident under moderate salinity (Table 1).

Table 1

Means of root and leaf soluble sugars, leaf CAT, APX, SOD and MDA content of faba bean for interaction of salinity $\times$ growth regulators

\begin{tabular}{|c|c|c|c|c|c|c|c|}
\hline Salinity & $\begin{array}{l}\text { Growth } \\
\text { regulators }\end{array}$ & $\begin{array}{l}\text { Root soluble } \\
\text { sugars } \\
(\mathrm{mg} / \mathrm{g} \mathrm{FW})\end{array}$ & $\begin{array}{l}\text { Leaf soluble } \\
\text { sugars } \\
(\mathrm{mg} / \mathrm{g} \mathrm{FW})\end{array}$ & $\begin{array}{c}\text { Leaf CAT } \\
(\mathrm{U} / \mathrm{mg} \\
\left.\text { Protein.min }{ }^{-1}\right)\end{array}$ & $\begin{array}{c}\text { Leaf APX } \\
(\mathrm{U} / \mathrm{mg} \\
\left.\text { Protein.min }{ }^{-1}\right)\end{array}$ & $\begin{array}{c}\text { Leaf SOD } \\
(\mathrm{U} / \mathrm{mg} \\
\left.\text { Protein.min }{ }^{-1}\right)\end{array}$ & $\begin{array}{c}\text { MDA } \\
(\mathrm{nmol} / \mathrm{g} \mathrm{FW})\end{array}$ \\
\hline \multirow{3}{*}{0} & Control & $8.06^{\mathrm{f}}$ & $10.4^{\mathrm{i}}$ & $0.49^{g}$ & $0.21^{\mathrm{i}}$ & $0.43^{\mathrm{g}}$ & $2.76^{\mathrm{i}}$ \\
\hline & BAP & $9.2^{\mathrm{ef}}$ & $12.51^{\mathrm{h}}$ & $0.54 \mathrm{~g}$ & $0.3^{\text {hi }}$ & $0.46^{\mathrm{g}}$ & $2.53^{\mathrm{i}}$ \\
\hline & SA & $9.43^{\mathrm{ef}}$ & $15.17 \mathrm{~g}$ & $0.74^{f g}$ & $0.39^{\mathrm{h}}$ & $0.63 \mathrm{~g}$ & $2.2^{\mathrm{i}}$ \\
\hline \multirow{3}{*}{4} & Control & $9.86^{\mathrm{e}}$ & $14.88 \mathrm{~g}$ & $1.08^{\mathrm{ef}}$ & $0.53 \mathrm{~g}$ & $1.12^{\mathrm{f}}$ & $6.1^{f}$ \\
\hline & BAP & $12.7^{\mathrm{d}}$ & $18.07^{f}$ & $1.23^{\mathrm{def}}$ & $0.7^{\mathrm{f}}$ & $1.45^{\mathrm{e}}$ & $5.03 \mathrm{~g}$ \\
\hline & SA & $14.6^{\mathrm{c}}$ & $22.22^{\mathrm{d}}$ & $1.66^{\mathrm{cd}}$ & $0.95^{\mathrm{e}}$ & $1.85^{\mathrm{d}}$ & $3.7^{\mathrm{h}}$ \\
\hline \multirow{3}{*}{8} & Control & $15.6^{\mathrm{c}}$ & $24.75^{\mathrm{c}}$ & $1.93^{\mathrm{c}}$ & $1.5^{\mathrm{c}}$ & $2.26^{c}$ & $8.06^{\mathrm{d}}$ \\
\hline & BAP & $17.17^{b}$ & $28.11^{\mathrm{b}}$ & $2.93^{b}$ & $1.7^{b}$ & $2.78^{b}$ & $6.86^{\mathrm{e}}$ \\
\hline & SA & $19.43^{\mathrm{a}}$ & $33.09^{\mathrm{a}}$ & $3.86^{\mathrm{a}}$ & $2.03^{\mathrm{a}}$ & $3.46^{\mathrm{a}}$ & $5.26^{\mathrm{g}}$ \\
\hline \multirow{3}{*}{12} & Control & $14.43^{c}$ & $20.53^{\mathrm{e}}$ & $1.4^{\mathrm{de}}$ & $1.23^{\mathrm{d}}$ & $1.86^{\mathrm{d}}$ & $13.87^{\mathrm{a}}$ \\
\hline & BAP & $15.13^{\mathrm{c}}$ & $23^{d}$ & $2.06^{\mathrm{c}}$ & $1.53^{\mathrm{c}}$ & $2.21^{\mathrm{c}}$ & $12.6^{\mathrm{b}}$ \\
\hline & SA & $17.73^{b}$ & $25.67^{\mathrm{c}}$ & $2.66^{\mathrm{b}}$ & $1.79^{\mathrm{b}}$ & $2.66^{\mathrm{b}}$ & $9.73^{\mathrm{c}}$ \\
\hline
\end{tabular}

Different letters in each column indicate significant difference at $\mathrm{P} \leq 0.05$. 


\section{Leaf $M D A$}

The significant interaction of salinity $\times$ growth regulators $(\mathrm{P} \leq 0.01)$ showed that the malondialdehyde (MDA) content of the leaf of GR treated and untreated plants was considerably enhanced by increasing salt stress. Exogenous applications of BAP and especially SA reduced the MDA content of plants subjected to different levels of salinity. The reduction in leaf MDA content due to SA treatment increased with increasing salinity (Table 1).

\section{Membrane stability index (MSI)}

Effect of salinity $(\mathrm{P} \leq 0.01)$ and growth regulators $(\mathrm{P} \leq 0.05)$ on membrane stability index was significant. MSI was linearly decreased by increasing salinity, with no significant difference between non-salinity and $4 \mathrm{dS} / \mathrm{m}$ salinity (Fig. 4A). Plants treated with SA showed the highest membrane stability index followed by BAP treatment. However, there was no significant difference between MSI of GR treated plants (Fig. 4B).
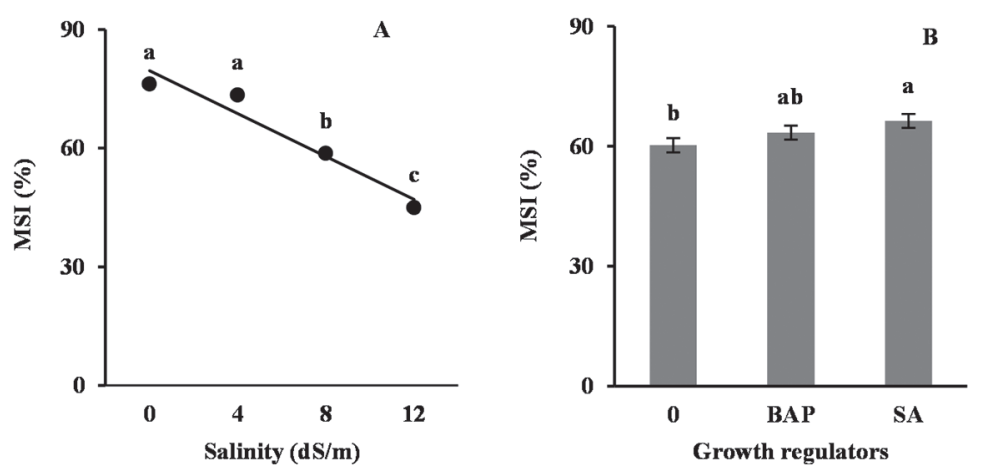

Fig. 4. Changes in membrane stability index (MSI) of faba bean leaves under different salinity (A) and growth regulators (B) treatments. Different letters indicate significant difference at $\mathrm{P} \leq 0.05$

\section{DISCUSSION}

One of the best known effects of $\mathrm{Na}$ stress on plant nutrition is suppression of $\mathrm{K}^{+}$ uptake. $\mathrm{K}^{+}$is an essential activator for many enzymes located in the cytosol [40] and also it is a crucial ion for osmotic adjustment, especially in old leaves [22]. Therefore, reduction of $\mathrm{K}^{+}$content can reduce plant growth. In our present study, increasing leaf $\mathrm{Na}^{+}$content damages cell membrane and reduces cell turgidity [38]. SA and BAP applications were found to be more effective in reducing $\mathrm{Na}^{+}$and improving $\mathrm{K}^{+}$and $\mathrm{K}^{+} / \mathrm{Na}^{+}$ratio in faba bean plants. The entry of $\mathrm{Na}^{+}$ions through the plasma membrane could lead to depolarization under salt stress [20]. This depolarization not only pre- 
vents $\mathrm{K}^{+}$uptake, but also increases $\mathrm{K}^{+}$leakage through depolarization-activated KOR channels [35]. Exogenous SA increases $\mathrm{H}^{+}$-ATPase activity under saline condition, which decreases the extent of plasma-membrane depolarization. This can reduce $\mathrm{NaCl}$-induced $\mathrm{K}^{+}$efflux and enhances $\mathrm{K}^{+}$retention. SA also decreases xylem loading of $\mathrm{Na}^{+}$in roots and reduces $\mathrm{Na}^{+}$translocation from roots to the shoots during longterm salt stress. The lower $\mathrm{Na}^{+}$content of the shoot is accompanied by higher $\mathrm{K}^{+}$ content and $\mathrm{K}^{+} / \mathrm{Na}^{+}$ratio, which is required for normal cell functioning under salinity. Application of BAP reduced $\mathrm{Na}^{+}$and enhanced $\mathrm{K}^{+}$contents of ryegrass leaves through increasing transcription of HKT which serves as $\mathrm{Na}^{+} / \mathrm{K}^{+}$co-transporter [11, 25], that inhibits the over-accumulation of $\mathrm{Na}^{+}$in the leaves [7].

Enhancing soluble sugar contents in faba bean roots and leaves due to salinity and plant growth regulator treatments is a major mechanism for osmotic adjustment and salt tolerance in plants. This could be associated with increasing chlorophyll content and subsequently promotion of photosynthetic apparatus efficiency [44]. Supporting the structure of membranes as a substitute for water [28] and also maintaining water homeostasis among different parts of the cell are key functions of the soluble sugars [37]. Exogenous SA and to a lesser extent BAP could lead to a better osmotic adjustment by increasing the accumulation of both $\mathrm{K}^{+}$and soluble sugars in roots and leaves as shown in our present study. Higher soluble sugar content of roots in comparison with leaves could be the result of more sugar transfer from leaves to roots [16]. Cytokinin and auxins are considerably diminished in the shoots due to salinity [13], which can reduce shoot growth. Salt-induced auxin accumulation in the roots enhances the ratio of auxin/cytokinin that may induce cell enlargement and root growth. Increasing assimilate transfer to the roots can be also explained by rising cell wall invertase activity in roots than in leaves [41]. High soluble sugar in roots increases osmotic pressure and enhances the ability of roots for water absorption from a waterstressed bed [16].

Excess and toxic ROS induced by salinity may cause damage to cell membranes. Increasing CAT, APX and SOD activities due to SA and BAP treatments under all levels of salinity can scavenge ROS and protect cell membrane (see Table 1). Super oxide dismutase converts superoxide radicals into hydrogen peroxide, which can be reduced to water and oxygen by catalase [12]. SA has a key role in ROS scavenging and reduction of oxidative stress in plants exposed to salt stress. Exogenous SA produces signals that enhance the activity of antioxidant enzymes in plants. Exogenous application of BAP on wheat [43] and perennial ryegrass plants [25] also increased antioxidant enzymes activities including APX, CAT and SOD under salinity.

Increasing leaf MDA content due to salinity observed in our present study is the consequence of lipid peroxidation in membranes. Increasing $\mathrm{H}_{2} \mathrm{O}_{2}$ content and subsequently peroxidation of lipids under stress leads to the loss of membrane permeability [19]. Reduction in MDA content in response to foliar sprays of BAP and particularly SA seems to directly be related with an increase in antioxidant enzymes activities (see Table 1). Application of SA was also effective in decreasing both MDA and electrolyte leakage in faba bean plants under saline and non-saline conditions [4]. 
The harmful effect of salinity on plant cell membranes can impair their ion selectivity, leading to the leakage of intracellular ions and organic solutions and ultimately disrupting physiological processes of plants [39]. The decreasing membrane stability index due to high salinity observed by us is the result of enhanced lipid peroxidation caused by ROS, whereas the improving membrane stability index in response to SA and BAP application could be attributed to the reduction of $\mathrm{Na}^{+}$accumulation and induction of antioxidant enzymes activities in faba bean plants, that protect the cell membranes from oxidative damage [36]. Therefore, exogenous application of BAP and particularly SA can considerably improve physiological performance of faba bean plants under saline and non-saline conditions.

\section{REFERENCES}

1. Abdelraouf, E. A. A., Adss, I. A. A., Dakroury, M. Z. (2016) Effect of salinity on growth and genetic diversity of broad bean (Vicia faba L.) cultivars. Alexandria Sci. Exchange J. 37, 467-479.

2. Aebi, H. (1984) Catalase in vitro. Meth. Enzymol. 105, 121-126.

3. Arfan, M., Athar, H. R., Ashraf, M. (2007) Does exogenous application of salicylic acid through the rooting medium modulate growth and photosynthetic capacity in two differently adapted spring wheat cultivars under salt stress? J. Plant Physiol. 164, 685-694.

4. Azooz, M. M., Youssef, A. M., Ahmad, P. (2011) Evaluation of salicylic acid (SA) application on growth, osmotic solutes and antioxidant enzyme activities on broad bean seedlings grown under diluted seawater. Int. J. Plant Physiol. Biochem. 3, 253-264.

5. Barciszewski, J., Siboska, G., Rattan, S. I. S., Clark, B. F. C. (2000) Occurrence, biosynthesis and properties of kinetin (N6-furfuryladenine). Plant Growth Regul. 32, 257-265.

6. Bradford, M. M. (1976) A rapid and sensitive method for the quantitation of microgram quantities of protein utilizing the principle of protein-dye binding. Anal. Biochem. 72, 248-254.

7. Byrt, C. S., Platten, J. D., Spielmeyer, W., James, R.A., Lagudah, E. S., Dennis, E. S., Tester, M., Munns, R. (2007) HKT1; 5-like cation transporters linked to $\mathrm{Na}^{+}$exclusion loci in wheat, Nax2 and Knal. Plant Physiol. 143, 1918-1928.

8. Cakmak, I., Horst, J. (1991) Effect of aluminium on lipid peroxidation, superoxide dismutase, catalase, and peroxidase activities in root tips of soybean (Glycine max). Physiol. Plant. 83, 463-468.

9. Chakrabarti, N., Mukherji, S. (2003) Alleviation of $\mathrm{NaCl}$ stress by pretreatment with phytohormones in Vigna radiata. Biol. Plantarum 46, 589-594.

10. Clarke, A., Desikan, R., Hurst, R. D. (2000) Nitric oxide and programmed cell death in Arabidopsis thaliana suspension cultures. Plant J. 24, 667-677.

11. Deinlein, U., Stephan, A. B., Horie, T., Luo, W., Xu, G., Schroeder, J. I. (2014) Plant salt-tolerance mechanisms. Trends Plant Sci. 19, 371-379.

12. El-Beltagi, H. S., Mohamed, A. A., Mekki, B. B. (2011) Differences in some constituents, enzymes activity and electrophoretic characterization of different rapeseed (Brassica napus L.) cultivars. Tom. XVIII. 1, 39-46.

13. Ghanem, M. E., Albacete, A., Martínez-Andújar, C., Acosta, M., Romero-Aranda, R., Dodd, I. C., Lutts, S., Pérez-Alfocea, F. (2008) Hormonal changes during salinity-induced leaf senescence in tomato (Solanum lycopersicum L.). J. Exp. Bot. 59, 3039-3050.

14. Giannopolitis, C. N., Ries, S. K. (1977) Superoxide dismutase I occurrence in higher plants. Plant Physiol. 59, 309-314.

15. Gunes, A., Inal, A., Alpaslan, M., Eraslan, F., Bagci, E. G., Cicek, N. (2007) Salicylic acid induced changes on some physiological parameters symptomatic for oxidative stress and mineral nutrition in maize (Zea mays L.) grown under salinity. J. Plant Physiol. 164, 728-736. 
16. Hajiboland, R., Radpour, E., Pasbani, B. (2014) Effect of phosphorus deficiency on drought stress tolerance in two tomato (Solanum lycopersum L.) cultivars J. Plant Res. (Iranian J. Biol.), 27, 788-803. (in English).

17. Hameed, A., Bibi, N., Akhter, J., Iqbal, N. (2011) Differential changes in antioxidants, proteases, and lipid peroxidation in flag leaves of wheat genotypes under different levels of water deficit conditions. Plant Physiol. Biochem. 49, 178-185.

18. Hameed, M., Nawaz, T., Ashraf, M., Naz, N., Batool, R., Ahmad, M. S. A., Riaz, A. (2013) Physioanatomical adaptations in response to salt stress in Sporobolus arabicus (Poaceae) from the salt range. Turk. J. Bot. 37, 715-724.

19. Jaleel, C. A., Lakshmanan, G. M., Gomathinayagam, M., Panneerselvam, R. (2008) Triadimefon induced salt stress tolerance in Withania somnifera and its relationship to antioxidant defense system. South Afric. J. Bot. 74, 126-132.

20. Jayakannan, M., Bose, J., Babourina, O., Rengel, Z., Shabala, S. (2013) Salicylic acid improves salinity tolerance in Arabidopsis by restoring membrane potential and preventing salt-induced $\mathrm{K}^{+}$loss via a GORK channel. J. Exp. Bot. 64, 2255-2268.

21. Johnson, S. M., Doherty, S. J., Croy, R. R. D. (2003) Biphasic superoxide generation in potato tubers. A self amplifying response to stress. Plant Physiol. 13, 1440-1449.

22. Jones, M. M., Turner, N. C. (1980) Osmotic adjustment in expanding and fully expanded leaves of sunflower in response to water deficits. Aust. J. Plant Physiol. 7, 181-192.

23. Katerji, N., Van Hoorn, J. W., Hamdy, A., Mastrorilli, M. (2003) Salinity effect on crop development and yield, analysis of salt tolerance according to several classification methods. Agric. Water Manage. 62, 37-66.

24. Kochert, G. (1978) Carbohydrate determination by the phenol sulfuric acid method. In: Hellebust, J. A., Craigie, J. S. (ed.) Handbook of Physiological Methods-Physiological and Biochemical Methods. Cambridge University Press, London, pp. 96-97.

25. Ma, X., Zhang, J., Huang, B. (2016) Cytokinin-mitigation of salt-induced leaf senescence in perennial ryegrass involving the activation of antioxidant systems and ionic balance. Environ. Exp. Bot. 125, $1-11$.

26. Maas, E. V., Hoffman, G. J. (1977) Crop salt tolerance, current assessment. J. Irrig. Drain Div. ASCE. 103, 115-134.

27. Maghsoudi, A., Maghsoudi, K. (2008) Salt stress on respiration and growth of germinated seeds of different wheat (Triticum aestivum L.) cultivars. World J. Agric. Sci. 4, 351-358.

28. Mundree, S. G., Baker, B., Mowla, Sh., Peters, Sh., Marais, S., Willigen, C. V., Govender, K., Mdredza, A., Muyanga, S., Farrant, J. M., Thomson, J. A. (2002) Physiological and molecular insights into drought tolerance. Afr. J. Biotechnol. 1, 28-38.

29. Munns, R. (2002) Comparative physiology of salt and water stress. Plant Cell Environ. 25, 239-250.

30. Munnus, R., James, R. A., Lanchli, A. (2006) Approaches to increasing the salt tolerance of wheat and other cereals. Plant Physiol. Biochem. 36, 767-772.

31. Nakano, Y., Asada, K. (1981) Hydrogen peroxide is scavenged by ascorbate-specific peroxidase in spinach chloroplasts. Plant Cell Physiol. 22, 867-880.

32. Pospíšilová, J., Synková, H., Rululcová, J. (2000) Cytokinins and water stress. Biol. Plantarum. 43, 321-328.

33. Sakr, M. T., Mohamed, Z. A., Atta, M. I., Zalama, M. T. (2014) Response of faba bean plants to application of some growth promoters under salinity stress conditions. J. Plant Prod. 5, 79-94.

34. Sarvajeet, S. G., Narendra, T. (2010) Reactive oxygen species and antioxidant machinery in abiotic stress tolerance in crop plant. Plant Physiol. Biochem. 48, 909-930.

35. Shabala, S., Cuin, T. A. (2008) Potassium transport and plant salt tolerance. Physiol. Plant. 133, 651-669.

36. Sharhrtash, M., Mohsenzadeh, S., Mohabatkar, H. (2011) Salicylic acid alleviates paraquat oxidative damage in maize seedling. Asian J. Exp. Biol. Sci. 2, 377-382.

37. Sidari, M., Santonoceto, C., Anastasi, U., Preiti, G., Muscolo, A. (2008) Variations in four genotypes of lentil under NaCl-salinity stress. Am. J. Agric. Biol. Sci. 3, 410-416. 
38. Sreenivasulu, N., Grimm, B., Wobns, U., Weschke, W. (2000) Different response of antioxidant compounds to salinity stress in salt-tolerant and salt-sensitive seedling of foxtail millet. Physiol. Plant. 109, 435-442.

39. Stevens, J., Senaratna, T., Sivasithamparam, K. (2006) Salicylic acid induces salinity tolerance in tomato (Lycopersicon esculentum cv. 'Roma'), associated changes in gas exchange, water relations and membrane stabilisation. Plant Growth Regul. 49, 77-83.

40. Tester, M., Davenport, R. (2003) $\mathrm{Na}^{+}$tolerance and $\mathrm{Na}^{+}$transport in higher plants. Ann. Bot. 91 , $503-527$.

41. Werner, T., Holst, K., Pörs, Y., Guivarc'h, A., Mustroph, A., Chriqui, D., Grimm, B., Schmülling, T. (2008) Cytokinin deficiency causes distinct changes of sink and source parameters in tobacco shoots and roots. J. Exp. Bot. 59, 2659-2672.

42. Xu, Q., Xu, X., Zhao, Y., Jiao, K., Herbert, J. S., Hao, L. (2008) Salicylic acid, hydrogen peroxide and calcium-induced salinity tolerance associated with endogenous hydrogen peroxide homeostasis in naked oat seedlings. Plant Growth Regul. 54, 249-259.

43. Yasmeen, A., Basra, S., Farooq, M., Ur Rehman, H., Hussain, N. (2013) Exogenous application of moringa leaf extract modulates the antioxidant enzyme system to improve wheat performance under saline conditions. Plant Growth Regul. 69, 225-233.

44. Yusuf, M., Aiman Hasan, S., Ali, B., Hayat, S., Fariduddin, Q., Ahmad, A. (2008) Effect of salicylic acid on salinity-induced changes in Brassica juncea. J. Integr. Plant Biol. 50, 1096-1102.

45. Zörb, C., Schamit, S., Need, A., Karl, S. (2004) The biochemical reaction of maize (Zea mays L.) to salt stress is characterized by mitigation of symptoms and not by specific adaptation. J. Plant Sci. 167, 91-100. 